\title{
KOMISI PEMBERANTASAN KORUPSI SEBAGAI LEMBAGA RASUAH DALAM PEMBERANTASAN TINDAK PIDANA KORUPSI DI INDONESIA
}

\author{
Aryas Adi Suyanto \\ Magister Hukum Universitas Semarang
}

\begin{abstract}
ABSTRAK
Tujuan dilakukannya penelitian ini adalah untuk memahami Komisi Pemberantasan Korupsi sebagai lembaga anti rasuah dan memahami penegakan hukum Komisi Pemberantasan Korupsi terhadap penyalahgunaan kewenangan yang dilakukan para penegak hukum dalam penyelesaian tindak pidana korupsi. Penelitian inmi menggunakan penelitian yuridis normative. Secara garis besar sasaran Komisi Pemberantasan Korupsi dalam penegakan hukum dibagi menjadi 4 (empat) bidang, yakni penindakan, pencegahan, koordinasi dan supervisi, serta monitoring. Ini dilakukan untuk melaksanakan tupoksidengan baik untuk menindak dengan tegas sesuai aturan hukum yang berlaku maupun mencegah Tindak Pidana Korupsi agar tidak terulang lagi dimasa depan. Untuk memerangi korupsi diperlukan komitmen kuat dan kerja sama serta koordinasi yang baik antar instansi pemerintah dan aparat penegak hukum. Tugas memberantas korupsi hanya dapat dilakukan apabila semua komponen bangsa bersatu dan saling mendukung dalam segala upaya pemberantasan korupsi.Undang-Undang Nomor 30 Tahun 2002 secara jelas sudah memberikan kewenangan kepada Komisi Pemberantasan Korupsi yang sangat kuat dan besar untuk melakukan pemberantasan korupsi secara sistemik dan tidak pandang bulu dalam menyeret para koruptor menjadikan Komisi Pemberantasan Korupsi sebagai tonggak utama dalam pemberantasan korupsi.
\end{abstract}

Kata Kunci: Penegakan hukum; korupsi; pemberantasan 
e-ISSN : 2621-4105

\title{
THE CORRUPTION ERADICATION COMMISSION AS A ROLE INSTITUTION IN ERADICATION OF CORRUPTION CRIME IN INDONESIA
}

\author{
Aryas Adi Suyanto \\ Master of Law, University of Semarang
}

\begin{abstract}
The purpose of this research is to understand the Corruption Eradication Commission as an anti-racial institution and understand the Corruption Eradication Commission's law enforcement against the misuse of authority by law enforcers in solving corruption. This research uses normative juridical research. Broadly speaking, the targets of the Corruption Eradication Commission in law enforcement are divided into 4 (four) fields, namely enforcement, prevention, coordination and supervision, and monitoring. This is done to carry out the tupoxid well to act firmly according to the applicable legal rules and prevent Corruption Crimes from being repeated in the future. To fight corruption requires strong commitment and cooperation and good coordination between government agencies and law enforcement officials. The task of eradicating corruption can only be carried out if all components of the nation unite and support one another in all efforts to eradicate corruption. Law Number 30 Year 2002 has clearly given authority to the Corruption Eradication Commission which is very strong and large to carry out corruption eradication systemically and not with perspective fur in dragging the corruptors to make the Corruption Eradication Commission as a major milestone in the eradication of corruption.
\end{abstract}

Keywords: Law enforcement; corruption; eradication 


\section{A. PENDAHULUAN}

Tujuan pembangunan Nasional adalah mewujudkan manusia Indonesia seutuhnya dan masyarakat yang adil, makmur, sejahtera dan tertib berdasarkan Pancasila dan Undang-undang dasar 1945.Untuk mewujudkan masyarakat Indonesia yang adil makmur dan sejahtera tersebut, perlu ditingkatkan secara terus menerus usaha-usaha pencegahan dan pemberantasan Tindak Pidana pada umumnya serta Tindak Pidana Korupsi pada khususnya. ${ }^{1}$

Tahun 1999 menjadi tonggak yang menyadarkan bangsa Indonesia bahwa ide pensakralan Undang-undang Dasar Negara Republik Indonesia Tahun 1945(selanjutnya disebut UUD Negara RI Tahun 1945) tidaklah relevan dalam kehidupan bernegara. Selama empat tahun dari tahun 1999 hingga tahun 2002, Majelis Permusyawaratan Rakyat (MPR) telah melakukan empat kali perubahan yang amat mendasar terhadap UUD Negara RI Tahun $1945 .^{2}$ Perubahan konstitusi tersebut telah mengubah secara mendasar pula cetak biru (blue print) ketatanegaraan Indonesia di masa yang akan datang. Secara kuantitatif, isi UUD Negara RI Tahun 1945telah mengalami perubahan lebih dari 300 persen. Naskah UUD Negara RI Tahun 1945 yang sebelumnya terdiri dari 71 butir ketentuan ayat atau pasal, saat ini menjadi memiliki 199 butir ketentuan. Hanya sekitar 25 butir yang sama sekali tidak berubah dari rumusan ketentuan yang asli, sementara sisanya sebanyak 174 butir merupakan ketentuan-ketentuan baru. Selain itu, bagian Pembukaan, yang secara substansi berasal dari Piagam Jakarta, juga tidak dijadikan obyek dalam perubahan tersebut. ${ }^{3}$

Korupsi telah menjadi penyakit yang muncul perlahan-lahan sebagai momok yang dapat membawa kehancuran bagi perekonomian Negara.Diakui atau tidak, praktik korupsi yang terjadi dalam bangsa ini telah menimbulkan banyak kerugian. Tidak saja bidang ekonomi, maupun juga dalam bidang politik, social budaya, maupun keamanan. ${ }^{4}$

Salah satu kewenangan KPK yang tertuang dalam Pasal 8 adalah wewenang penyidikan dan penuntutan. Hal tersebut dimuat dalam Pasal 8 ayat (2) yang

\footnotetext{
${ }^{1}$ HarieTuesang, Seminar pencegahan dan pemberantasan korupsi Topik II, Hal 1

${ }^{2}$ Jimly Asshiddiqie, Pengantar Ilmu Hukum Tata Negara Jilid II, Sekertariat Jenderal dan Kepaniteraan Mahkamah Konstitusi RI Jakarta, 2006, hal 2.

${ }^{3}$ ibid

${ }^{4}$ DeniStyawati, 2008, KPK PemburuKoruptor, Cet I, PustakaTimur, Yogyakarta, hal. 1.
} 
menyebutkan bahwa Komisi pemeberantasan Korupsi berwenang juga mengambil alih penyidikan dan penuntutan terhadap pelaku tindak pidana korupsi yang sedang dilakukan oleh kepolisian atau kejaksaan. Pengaturan dalam Pasal 8 ayat (2) tersebut dibatasi oleh alasan yang tertuang dalam pasal 9 Undang-Undang KPK tersebut.

Dalam pengaturan Pasal 9 tersebut,KPK dapat mengambilalih penyidikan dan penuntutan yang dilakukan kepolisian kasus tindak pidana korupsi yang sedang ditangani oleh kepolisian dan kejaksaan apabila telah memenuhi alasan-alasan yang diatur dalam Pasal 9 UU KPK diantaranya laporan masyarakat mengenai tindak pidana korupsi tidak ditindaklanjuti atau proses penanganannya berlarut-larut atau tertundatunda tanpa alasan yang dapat dipertanggungjawabkan atau penanganannya ditujukan untuk melindungi pelaku tindak pidana korupsi yang sesungguhnya atau karena ada hambatan penanganan tindak pidana korupsi karena campur tangan dari eksekutif, yudikatif, atau legislative.

Terkait tentang luasnya kewenangan yang dimiliki KPK ada potensi kekaburan norma dalam pemberian wewenang Lembaga tersebut. Penyebab utama adanya kekaburan norma dalam kewenangan lembaga negara tersebut adalah Undang-Undang KPK, termasuk Undang-Undang Tipikor itu sendiri. Karena Undang-Undanglah yang masih belum bisa memberikan penjelasan terkaitmengenai unsur-unsur yang telah dimuat dalam Undang-Undang sebagai kewenangan lembaga Negara itu sendiri.

Berdasaran latar belakang tersebut, maka diberi sebuah judul yakni :"Komisi Pemberantasan Korupsi Sebagai Lembaga Anti Rasuah Dalam Pemberantasan Tindak Pidana Korupsi Di Indonesia".

\section{B. PERMASALAHAN}

Berdasarkan latar belakang yang telah diuraikan di atas, terdapat beberapa permasalahan yang penting untuk dibahas, yaitu :

1. Bagaimana Komisi Pemberantasan Korupsi sebagai lembaga anti rasuah dalam pemberantasan tindak pidana korupsi? 
2. Bagaimanakah Penegakan hukum oleh KPK terhadap penyalahgunaan kewenangan yang dilakukan oleh penegak hukum dalam penyelesaian tindak pidana korupsi?

\section{METODE PENELITIAN}

Metode adalah proses, prinsip-prinsip dan tata cara memecahkan suatu masalah, sedangkan penelitian adalah pemeriksaan secara hati-hati, tekun dan tuntas terhadap suatu gejala untuk menambah pengetahuan manusia, maka metode penelitian dapat diartikan sebagai proses, prinsip-prinsip dan tata cara untuk memecahkan masalah yang dihadapi dalam melakukan penelitian. ${ }^{5}$

Metode yang digunakan dalam penelitian ini adalah penelitian yuridis Normatif, yaitu metode yang melakukan penelitian bahan kepustakaan (data Sekunder), mencakup asas-asas hukum,sitematik hukum, sinkronisasi vertical dan horizontal (Peraturan Perundang-Undangan Yang berkaitan),Penelitian menggunakan metode pendekatan perundang-undangan,analisa konsep hukum, perbandingan Hukum.

Spesifikasi penelitian ini adalah penelitian deskriptif analitis, yaitu suatu penelitian yang berusaha menggambarkan masalah hukum dan mengkajinya atau menganalisisnya sesuai dengan kebutuhan dari penelitian yang bersangkutan. ${ }^{6}$

Secara umum jenis data yang diperlukan dalam suatu penelitian hukum terarah pada penelitian data sekunder dan primerPenelitian ini menggunakan jenis sumber data sekunder, yaitu data yang mendukung keterangan atau menunjang kelengkapan Data Primer yang diperoleh dari perpustakaan dan koleksi pustaka pribadi penulis terdiri dari :

1) Bahan hukum primer adalah bahan hukum yang mempunyai kekuatan mengikat dalam masyarakat. Bahan hukum sekunder adalah bahan hukum yang dapat menginformasikan sumber hukum primer, sedangkan bahan hukum tersier adalah

\footnotetext{
${ }^{5}$ Soerjono Soekanto, Pengantar Penelitian Hukum, Jakarta UI Press, 1986, hlm. 6

${ }^{6}$ Pedoman penulisan Usulan Penelitian dan Tesis, Semarang: Program Studi Magister Ilmu Hukum, Program pascasarjana Universitas Semarang, 2009, hlm. 6
} 
bahan yang memberikan petunjuk atau penjelasan mengenai sumber hukum primer dan sekunder, ${ }^{7}$

2) Bahan hukum sekunder, yaitu bahan yang memberikan penjelasan mengenai bahan hukum primer, seperti hasil-hasil seminar atau pertemuan ilmiah lainnya, bahkan dokumen pribadi atau pendapat dari kalangan pakar hukum yang relevan dengan objek telaah penelitian ini.

Analisis data merupakan suatu upaya pencarian dan menata secara sistematis catatan hasil observasi, dan lainnya untuk meningkatkan pemahaman peneliti tentang kasus yang diteliti dan menyajikan sebagai temuan bagi orang. Sedangkan kaidah kualitatif adalah proses analisis tersebut ditujukan untuk mengembangkan teori dengan jalan membandingkan teori bandingan dengan dengan tujuan untuk mmenemukan teori baru yang dapat berupa penguatan terhadap teori lama maupun melemahkan teori yang ada tanpa menggunakan rumus statistik. ${ }^{8}$

Setelah analisis data selesai maka hasilnya akan disajikan secara deskriptif yaitu dengan menuturkan dan menggambarkan apa adanya sesuai sesuai dengan permasalahan yang diteliti. ${ }^{9}$

\section{PEMBAHASAN}

\section{I.Pembentukan Komisi Pemberantasan Korupsi}

Komisi Pemberantasan Korupsi atau disingkat menjadi KPK, adalah Instansi penegak hukum di Indonesia yang dibentuk pada tahun 2003 untuk mengatasi, menanggulangi dan memberantas korupsi di Indonesia. Komisi ini dibentuk berdasarkan kepada Undang-Undang Republik IndonesiaNomor 30 Tahun 2002 tentang Komisi Pemberantasan Tindak Pidana Korupsi. KPK diberi amanat melakukan pemberantasan korupsi secara profesional, intensif, dan berkesinambungan karena korupsi telah merugikan keuangan Negara, perekonomian Negara, dan menghambat pembangunan nasional.

Pembentukan KPK bukanlah dibentuk dengan secara tiba-tiba, KPK dibentuk tanggal 27 Desember 2002 pada masa kepemimpinan Presiden Megawati Soekarno

\footnotetext{
${ }^{7}$ Sri Mamudji at al. Metode Penelitian dan Penulisan Hukum, Jakarta: Badan Penerbit Fakultas Hukum Universitas Indonesia, 2005, hlm. 31

${ }^{8}$ Sudarman Danim, Menjadi Peneliti Kualitatif, Bandung. CV. Pustaka Setia 2002, hlm. 41

${ }^{9}$ HB. Sutopo, Penelitian Kualitatif Baagian II, (Surakarta:UNS Press, 1988), halaman 37.
} 
Putri, sekalipun gagasan perlunya lembaga ini dibentuk telah lahir pada masa kepemimpinan Presiden B.J. Habibie. Jika ditinjau dari aspek historis pemberantasan korupsi di Indonesia, KPK bukanlah institusi pertama yang pernah dibentuk untuk memberantas korupsi di Indonesia. Sejarah mencatat sejak periode tahun 1963 - 2002, setidaknya sudah delapan lembaga/tim pemberantasan tindak pidana korupsi pernah dibentuk sebagai upaya pemberantasan korupsi;

1. Panitia Retooling Aparatur Negara (PARAN),

2. Operasi BUDHI, melalui Keputusan Presiden No. 275 Tahun 1963,

3. Tim Pemberantasan Korupsi (1967) tanggal 2 Desember 1967, melalui Keppres No. 228/1967,

4. Komisi Empat, melalui Keppres No. 12/1970 tertanggal 31 Januari 1970,

5. Operasi Penertiban, Tahun 1977 melalui Inpres No. 9/1977,

6. Tim Pemberantasan Korupsi (1982),

7. Komisi Pemeriksa Kekayaan Penyelenggara Negara, UU Nomor 31 Tahun 1999 tentang Pemberantasan Tindak Pidana Korupsi,

8. Tim Gabungan Pemberantasan Tindak Pidana Korupsi, melalui Peraturan Pemerintah Nomor 19 tahun 2000.

Komisi Pemberantasan Korupsi (KPK) dibentuk karena pemberantasan tindak pidana korupsi yang terjadi sampai sekarang belum dapat dilaksanakan secara optimal. Oleh karena itu pemberantasan korupsi perlu ditingkatkan secara professional, intensif, dan berkesinambungan. Tujuan dibentuknnya KPK itu sendiri tidak lain adalah untuk meningkatkan daya guna dan hasil guna terhadap upaya pemberantasan tindak pidana korupsi.Karena korupsi telah merugikan keuangan negara, perekonomian negara, dan menghambat pembangunan nasional begitu parahnya maka korupsi di Indonesia sudah dikategorikan sebagai tindak pidana luar biasa (extra ordinary crime). Cara penanganan korupsi harus dengan cara yang luar biasa. Untuk itulah dibentuk KPK yang mempunyai wewenang luar biasa, sehingga kalangan hukum menyebutnya sebagai suatu lembaga super (super body). 
Pimpinan Komisi Pemberantasan Korupsi terdiri dari 5 (lima) orang yang merangkap sebagai Anggota yang semuanya adalah pejabat negara. Pimpinan tersebut terdiri atas unsur pemerintah dan unsur masyarakat sehingga sistem pengawasan yang dilakukan oleh masyarakat terhadap kinerja KPKdalam melakukan penyelidikan, penyidikan, dan penuntutan terhadap tindak pidana korupsi tetap melekat pada Komisi Pemberantasan Korupsi.

Berdasarkan Pasal 3 Undang-Undang Nomor 30 Tahun 2002, Komisi Pemberantasan Korupsi sebagai lembaga independen bebas dari pengaruh kekuasaan manapun, artinya tidak boleh ada intervensi dari pihak lain dalam penyelidikannya agar diperoleh hasil sebaik mungkin. Yang dimaksud dengan 'kekuasaan manapun' adalah kekuatan yang dapat mempengaruhi tugas dan wewenang Komisi Pemberantasan Korupsi atau anggota KPK secara individual dari pihak eksekutif, yudikatif, legislatif, pihak-pihak lain yang terkait dengan perkara tindak pidana korupsi, atau keadaan dan situasi ataupun dengan alasan apapun.

\section{Komisi Pemberantasan Korupsi (KPK) sebagai lembaga anti rasuah dalam}

\section{Upaya Pemberantasan Korupsi di Indonesia}

Komisi Pemberantasan Korupsi (KPK) dibentuk berdasarkan Undang-Undang Nomor 30 Tahun 2002 tentang Komisi Pemberantasan Tindak Pidana Korupsi, KPK diberi amanat melakukan pemberantasan korupsi secara profesional, intensif, dan berkesinambungan. KPK merupakan lembaga negara yang bersifat independen, yang dalam melaksanakan tugas dan wewenangnya bebas dari kekuasaan manapun.

Untuk melakukan peranannya KPK diberikan kewenangan yang luar biasa seperti yang diatur dalam Pasal 6 butir b, c, d dan e UU. No. 30 tahun 2002 tentang Komisi Pemberantasan Tindak Pidana Korupsi bahwa lembaga ini dapat bertindak mulai dari:

Mensupervisi terhadap instansi yang berwenang melakukan tindak pidana korupsi, 
1. Koordinasi dengan instansi yang berwenang melakukan pemberantasan tindak pidana korupsi,

2. Melakukan penyelidikan, penyidikan, dan penuntutan terhadap tindak pidana korupsi,

3. Melakukan tindakan pencegahan korupsi,

4. Memonitor terhadap penyelenggaraan pemerintahan negara.

Untuk memerangi tindak pidana korupsi yang dikategorikan sebagai tindak pidana luara biasa (extra ordinary crime), maka KPK diberi tambahan kewenangan yang tidak dimiliki instititusi lain yaitu:

1. Melakukan penyadapan dan merekam pembicaraan;

2. Memerintahkan kepada instansi yang terkait untuk melarang seseorang berpergian keluar negeri;

3. Meminta keterangan kepada bank atau lembaga keuangan lainnya tentang keadaan keuangan tersangka atau terdakwa yang sedang diperiksa;

4. Memerintahkan kepada bank atau lembaga keuangan lainnya untuk memblokir rekening yang diduga hasil dari korupsi milik tersangka, terdakwa, atau pihak lain yang terkait;

5. Meminta data kekayaan dan data perpajakan tersangka atau terdakwa kepada instansi terkait;

6. Menghentikan sementara suatu transaksi keuangan, transaksi perdagangan, dan perjanjian lainnya atau pencabutan sementara perizinan, lisensi serta konsesi yang dilakukan atau dimiliki oleh tersangka atau terdakwa yang diduga berdasarkan bukti awal yang cukup ada hubungannya dengan tindak pidana korupsi yang sedang diperiksa;

7. Meminta bantuan interpol Indonesia atau instansi penegak hukum negara lain untuk melakukan pencarian, penangkapan, dan penyitaan barang bukti diluar negeri; 
8. Meminta bantuan kepolisian atau instansi lain yang terkait untuk melakukan penangkapan, penahanan, penggeledahan, dan penyitaan dalam perkara tindak pidana korupsi yang sedang ditangani.

Melihat kewenangan yang dimiliki oleh KPK, maka tidak heran kalau kalangan hukum menyebutnya sebagai lembaga super (superbody). Disamping itu, peranan KPK melebihi dari Kepolisian dan Kejaksaan dimana Kepolisian dan Kejaksaan dapat mengeluarkan Surat Perintah Penghentian Penyidikan dan Penuntutan (SPPP) dalam perkara tindak pidana korupsi, sebaliknya berdasarkan Pasal 40 UU Nomor 30 Tahun 2002, KPK tidak berwenang mengeluarkan SPP untuk menghindari adanya main mata antara tersangka dan aparat KPK. Dengan kewenangan yang super tersebut KPK mampu mengeliminasi korupsi secara konseptual dan sistematis.

Melihat dari sikap KPK yang tergolong tegas dan tepat itu, mungkin menjadi terapi shock kepada para koruptor lainnya. Secara tidak langsung kewenagan KPK yang terkadang dianggap melanggar privasi seseorang, menjadi salah satu hal yang dapat membuat orang untuk berpikir ulang untuk melakukan tindak pidana korupsi karena takut ditangkap oleh KPK yang datang seperti angin tanpa bisa diduga.

1. Isu Upaya Pelemahan terhadap Komisi Pemberantasan Korupsi

Selama ini Komisi Pemberantasan Korupsi (KPK)berusaha melaksanakan tugas yang diamanahkan oleh undang-undang dengan semaksimal mungkin memanfaatkan kewenangan yang ada. Undang-Undang No. 30 Tahun 2002 tentang KPK memberi kewenangan - kewenangan yang begitu besar kepada KPK, menjadikannya sebagai lembaga super (super body) satu-satunya di Indonesia di bidang penegak hukum.Namun, sebagai lembaga super yang mempunyai wewenang yang luar biasa, sekarang justru menjadi bumerang untuk KPK itu sendiri.

Sejak didirikan pada tahun 2003, KPK banyak menghadapi masalah kriminalitas terhadap para pimpinannya (KPK) yang dianggap sebagai ajang balas dendam oleh orang-orang yang selama ini dijerat kasus korupsi. Dimulai ketika 
pimpinan KPK, Antasari Azhar terseret kasus pembunuhan Nazaruddin Zulkarnaen, dan menyusul pimpinan-pimpinan KPK lainnya yang juga tersandung kasus hukum yang penuh dengan konspirasi dan kejanggalan. Yang lebih ironisnya upaya-upaya besar untuk melemahkan KPK datang dari Polri dan DPR. Komisi Pemberantasan Korupsi (KPK) yang sudah lemah, dan tak berdaya masih dihantam bertubi-tubi oleh berbagai rekayasa dan persekongkolan para elite politik.

Spirit pemberantasan korupsi telah mati di tangan kekuasaan yang cenderung melindungi kepentingan-kepentingan pihak tertentu di lingkaran kekuasaan. Pada 6 Mei 2015, Presiden Jokowi menerbitkan Inpres Nomor 7 / 2015 tentang Aksi Pencegahan dan Pemberantasan Korupsi (Aksi PPK). Inpres ini pada intinya melimpahkan tugas pemberantasan korupsi kepada lembaga dan instansi pemerintah. KPK ditempatkan sejajar dengan Kejagung dan Polri. Tugas KPK diarahkan lebih kepada upaya pencegahan korupsi. Upaya melemahkan KPK mencapai puncaknya saat diajukannya usulan revisi UU Nomor 30 tahun 2002 tentang KPK.

Pemerintah (DPR) berdalih bahwa tujuan utama revisi UU KPK mutlak untuk memperkuat KPK demi kepentingan rakyat. Revisi ini diharapkan mencegah adanya penyalahgunaan Institusi KPK untuk kepentingan individu atau kelompok tertentu. Namun, wacana memasukkan revisi Undang-Undang Nomor 30 Tahun 2002 tentang Komisi Pemberantasan Korupsi menunjukkan upaya sejumlah pihak untuk melemahkan lembaga anti korupsi tersebut. Ini karena draf revisi UU tersebut berisi sejumlah hal untuk melemahkan KPK. Berikut ini beberapa usulan yang melemahkan KPK dari revisi UU KPK yang diajukan oleh DPR :

a. Umur KPK dibatasi hanya 12 tahun

Pasal 5 dan pasal 73 revisi UU KPK ini menyebutkan secara spesifik bahwa usia KPK hanya 12 tahun sejak revisi UU KPK disahkan.Menurut KPK, tidak perlu dilakukan pembatasan masa kerja KPK. Sebab, pasal 2 angka 2 TAP 
MPR No. 8 tahun 2001 mengamanatkan pembentukkan KPK dan tidak disebutkan adanya pembatasan waktu.

b. KPK tidak lagi miliki tugas dan kewenangan lakukan penuntutan

Revisi UU KPK menghapuskan tugas dan kewenangan di bidang penuntutan. Hal ini tercantum dalam pasal 53 revisi UU KPK.Implikasi dari pasal ini adalah KPK tidak lagi memiliki kewenangan menuntut, dan proses penanganan perkara di lembaga antirasuah akan diserahka kepada kepolisian.

c. KPK kehilangan tugas dan kewenangan monitoring.

Selain hilangnya penuntutan, revisi UU KPK juga menghilangkan tugas KPK dalam melakukan monitoring.

d. KPK hanya bisa tangani perkara korupsi dengan kerugian negara Rp 50 miliar ke atas.

Ini berarti bahwa KPK harus menyerahkan penyidikan kepada kepolisian dan kejaksaan. Menurut ICW, jika berkaca dari UU No. 30 tahun 2002 tentang KPK yang berlaku sekarang, nilai kerugian negara yang ditentukan bagi KPK hanya sebesar Rp 1 miliar. Dengan angka ini, ada banyak perkara korupsi besar (grand corruption) yang juga berhasil diungkap oleh KPK. Menurut KPK, pembatasan ini tidak mendasar karena lembaga ini fokus kepada subyek hukum, bukan pada kerugian negara.

e. KPK lebih diarahkan pada tugas pencegahan Korupsi.

Diatur dalam pasal 1 angka 3, yang berbunyi:"Pemberantasan korupsi adalah serangkaian kegiatan untuk mencegah dan memberantas terjadinya tindak pidana korupsi melalui koordinasi, supervisi, monitoring penyelenggaraan negara yang berpotensi terjadinya tindak pidana korupsi."

f. KPK tidak dapat membuat perwakilan di daerah provinsi.

Dalam UU KPK yang saat ini berlaku, pasal 16, KPK memiliki kewenangan untuk membentuk kantor perwakilan di daerah provinsi. 
g. KPK harus mendapatkan izin ketua pengadilan untuk lakukan penyadapan.

Izin penyadapan ini diatur dalam pasal 14 ayat 1 huruf a RUU KPK. Pada intinya, mewajibkan KPK untuk memperoleh izin penyadapan dari ketua Pengadilan Negeri. Menurut KPK, berdasar putusan Mahkamah Konstitusi tahun 2003, MK menyatakan bahwa kewenangan penyadapan KPK tidak melanggar konstitusi sehingga perlu dipertahankan. Dan selama ini kewenangan menyadap sangat mendukung keberhasilan KPK memberantas korupsi. Jika dicabut, akan melemahkan upaya pemberantasan korupsi.

h. KPK dapat menghentikan penyidikan dan penuntutan perkara korupsi.

Salah satu keistimewaan KPK saat ini adalah tidak adanya mekanisme penerbitan Surat Perintah Penghentian Penyidikan (SP3) dan juga penuntutan (pasal 40 UU KPK). Menurut ICW, hal ini adalah salah satu parameter yang menjamin kualitas penanganan perkara di KPK yang harus dipastikan sangat matang.

i. KPK tidak bisa melakukan rekrutmen pegawai secara mandiri.

Pasal 25 ayat 2 revisi menyebutkan bahwa KPK tidak bisa melakukan rekrutmen pegawai mandiri. Yang dapat menjadi pegawai KPK adalah pegawai negeri yang berasal dari Kepolisian Republik Indonesia, Kejaksaan Republik Indonesia, Badan Pemeriksa Keuangan dan Pembangungan, dan Kementerian Komunikasi dan Informasi. Menurut KPK, lembaga ini harus diberikan kewenangan rekruitmen pegawai mandiri, termasuk mengangkat penyelidik, penyidik, penuntut umum. Mereka diangkat langsung oleh pimpinan KPK berdasar kompentensi bukan status sebagai polisi atau jaksa.

j. KPK wajib lapor ke kejaksaan dan Polri ketika tangani perkara korupsi.

Pasal 52 menyebutkan bahwa KPK wajib memberi notifikasi (pemberitahuan) kepada kepolisian dan kejaksaan ketika menangani perkara korupsi.Kewajiban ini menempatkan KPK dalam posisi di bawah kejaksaan 
dan kepolisian, karena dalam revisi UU ini, kewajiban tersebut hanya ada bagi KPK, tapi tidak bagi kejaksaan dan kepolisian.

k. KPK tidak dapat mengangkat penyelidik dan penyidik secara mandiri.

Serupa dengan definisi pegawai KPK yang disebutkan dalam pasal 25 ayat (2) revisi UU KPK, ke depannya penyelidik dan penyidik KPK pun dibatasi hanya dapat dipilih dari unsur kepolisian dan kejaksaan, berdasarkan usulan dari masing-masing lembaga, sebagaimana disebutkan dalam pasal 41 ayat (3) revisi UU KPK.

1. Pemberhentian penyelidik dan penyidik harus berdasarkan usulan kejaksaan dan Polri.

Selain pengangkatan penyelidik dan penyidik yang harus didasarkan oleh usulan kejaksaan dan Polri, pasal 45 ayat (1) revisi UU KPK menyebutkan pula bahwa pemberhentian penyelidik dan penyidik juga harus didasarkan oleh usulan dari kejaksaan dan Kepolisian.

m. Pimpinan KPK berumur sekurangnya 50 tahun.

Berdasar pasal 30 revisi UU KPK, salah satu syarat menjadi pimpinan KPK adalah berumur sekurang-kurangnya 50 tahun dan setinggi-tinginya 65 tahun.

n. Dewan Kehormatan

Kewenangan dari Dewan Kehormatan sangat besar, salah satunya adalah kewenangan melakukan pemberhentian sementara dan pemberhentian tetap sebagai pegawai KPK.

o. Dewan Eksekutif

Revisi UU KPK menambahkan satu lagi bagian dari organisasi KPK yaitu, Dewan Eksekutif. Seperti disebutkan dalam pasal 23 ayat 6 RUU KPK, keberadaan anggota Dewan Eksekutif yang diangkat dan diberhentikan oleh Presiden. Ada kekhawatiran dari kalangan aktivis antikorupsi, dewan eksekutif adalah titipan Istana. 
Langkah DPR merevisi UU KPK dinilai sengaja untuk melindungi koruptor. MenurutPengajar Fakultas Hukum Universitas Gadjah Mada, Zainal Arifin Mochtar, mengatakan, meski DPR ingin melemahkan KPK dan bahkan membubarkan lembaga anti rasuah ini, langkah tersebut tak akan berhasil tanpa dukungan pemerintah.

Dalam sidang paripurna DPR, 23 Juni 2015, wakil rakyat kompak mengesahkan revisi UU KPK masuk dalam Program Legislasi Nasional (Prolegnas) 2015. Akan tetapi pada 19 Juni 2015, Presiden Jokowi sudah menyatakan menolak revisi tersebut. Karena Presiden Jokowi menilai bahwa revisi RUU KPK yang diajukan DPR hanya akan melemahkan keberadaan KPK sebagai penegak hukum dalam memberantas tindak pidana korupsi.

KPK diberi amanat melakukan pemberantasan korupsi secara profesional, intensif, dan berkesinambungan.KPK merupakan lembaga negara yang bersifat independen, yang dalam melaksanakan tugas dan wewenangnya bebas dari kekuasaan manapun.KPK dibentuk bukan untuk mengambil alih tugas pemberantasan korupsi dari lembagalembaga yang ada sebelumnya. Penjelasan undang-undang menyebutkan peran KPK sebagai trigger mechanism, yang berarti mendorong atau sebagai stimulus agar upaya pemberantasan korupsi oleh lembaga-lembaga yang telah ada sebelumnya menjadi lebih efektif dan efisien. Dalam pelaksanaan tugasnya, KPK berpedoman kepada lima asas, yaitu kepastian hukum, keterbukaan, akuntabilitas, kepentingan umum, dan proposionalitas. KPK bertanggung jawab kepada publik dan menyampaikan laporannya secara terbuka dan berkala kepada Presiden, DPR, dan BPK.

Pimpinan KPK membawahi empat bidang, yang terdiri atas bidang Pencegahan, Penindakan, Informasi dan Data, serta Pengawasan Internal dan Pengaduan Masyarakat.Masing-masing bidang tersebut dipimpin oleh seorang deputi.KPK juga dibantu Sekretariat Jenderal yang diangkat dan diberhentikan oleh Presiden Republik Indonesia, namun bertanggung jawab kepada pimpinan KPK. 
Ketentuan mengenai struktur organisasi KPK diatur sedemikian rupa sehingga memungkinkan masyarakat luas tetap dapat berpartisipasi dalam aktivitas dan langkah-langkah yang dilakukan KPK.Dalam pelaksanaan operasional, KPK mengangkat pegawai yang direkrut sesuai dengan kompetensi yang diperlukan. ${ }^{10}$ Dalam hal struktur kelembagaan Komisi Pemberantasan Korupsi tidak lebih tinggi dari Kejaksaan maupun Kepolisian.Independensi KPK dilihat dari segi fungsionalnya.Komisi Pemberantasan Korupsi memiliki kedudukan yang lebih tinggi dari segi fungsi KPK ini, dan sebagai bagian dari constitutionalimportance KPK.Komisi Pemberantasan Korupsi juga independen dalam hal personal untuk melaksanakan tugas dan tanggung jawabnya.

KPK merupakan lembaga negara yang bersifat independen yang dalam melaksanakan fungsi dan kewenangannya bebas dari pengaruh kekuasaan manapun. Berdasarkan Pasal 6 dan 7 Undang Undang Nomor 30 Tahun 2002, maka tugas dari KPK ini meliputi: melakukan koordinasi dan supervisi terhadap upaya pemberantasan korupsi yang dilakukan oleh lembaga-lembaga yang berwenang, melakukan penyelidikan, penyidikan, dan penuntutan terhadap tindak pidana korupsi, melakukan tindakan-tindakan pencegahan tindak pidana korupsi, dan melakukan monitor terhadap penyelenggaraan pemerintahan negara. ${ }^{11}$ Tugas dan wewenang Komisi Pemberantasan Korupsi menurut UU No. 30 Tahun 2002 pasal 6 dan 7 :

\section{Pasal 6}

Komisi Pemberantasan Korupsi mempunyai tugas:

a. koordinasi dengan instansi yang berwenang melakukan pemberantasan tindak pidana korupsi;

b. supervisi terhadap instansi yang berwenang melakukan pemberantasan tindak pidana korupsi;

c. melakukan penyelidikan, penyidikan, dan penuntutan terhadap tindak pidana korupsi;

d. melakukan tindakan-tindakan pencegahan tindak pidana korupsi; dan

e. melakukan monitor terhadap penyelenggaraan pemerintahan negara.

${ }^{10}$ (http://www.kpk.go.id/id/tentang-kpk/sekilas-kpk).

11 Titik Triwulan Tutik, Konstruksi Tata Negara Indonesia, Kencana, Jakarta 2010, Hal 238 


\section{Pasal 7}

Dalam melaksanakan tugas koordinasi sebagaimana dimaksud dalam Pasal 6 huruf a, Komisi Pemberantasan Korupsi berwenang :

a. mengkoordinasikan penyelidikan, penyidikan, dan penuntutan tindak pidana korupsi;

b. menetapkan sistem pelaporan dalam kegiatan pemberantasan tindak pidana korupsi;

c. meminta informasi tentang kegiatan pemberantasan tindak pidana korupsi kepada instansi yang terkait;

d. melaksanakan dengar pendapat atau pertemuan dengan instansi yang berwenang melakukan pemberantasan tindak pidana korupsi; dan

e. meminta laporan instansi terkait mengenai pencegahan tindak pidana korupsi. ${ }^{12}$

Secara garis besar tugas dan wewenang KPK di bagi menjadi empat bidang, yakni penindakan, pencegahan, koordinasi dan supervis, serta monitoring. Tentu saja ada perbedaan karakteristik dari empat bagian tersebut.Bidang penindakan lebih kepada pemberian hukuman.Tujuan dari penindakan ini adalah memberi efek jera pada pelaku korupsi. Dan diharapkan terjadi efisiensi dan tranparansi pada pelayanan publik, serta mengembalikan keuangan negara yang sudah di tilap yang dilakukan dengan cara $:^{13}$

a. Penindakan korupsi dilakukan bersama-sama dengan aparat penegak hukum lainnya (Polri dan Kejaksaan).

b. Menangani kasus-kasus korupsi yang belum selesai dikerjakan oleh pimpinan KPK yang lama

c. Menanganani kasus-kasus yang menimbulkan dampak ikutan kumulatif yang tinggi, sedangkan kasus-kasus yang ber-scope lokal dilimpahkan kepada aparat penegak hukum daerah.

d. Menangani kasus-kasus korupsi di lingkungan aparat penegak hukum, pemasukan dan pengeluaran keuangan negara, serta sektor pelayanan publik.

\footnotetext{
${ }^{12}$ Diana Napitupulu, Op.Cit, hal 56

${ }^{13}$ bid
} 
e. Menindaklanjuti MoU dengan Dephan untuk mendorong penanganan kasus-kasus korupsi di lingkungan TNI.

Bidang berikutnya adalah pencegahan, dalam melakukan kegiatan yang dapat mengoptimalkan perbaikan layanan pada pelayanan publik serta mengefektifkan pengawasan seperti :

f. Mendorong segenap instansi dan masyarakat untuk meningkatkan kesadaran anti korupsi dan peran sertanya dalam pencegahan korupsi di lingkungan masingmasing.

g. Melakukan proaktif investigasi (deteksi) untuk mengenali dan memprediksi kerawanan korupsi dan potensi masalah penyebab korupsi secara periodik untuk disampaikan kepada instansi dan masyarakat yang bersangkutan.

h. Mendorong lembaga dan masyarakat untuk mengantisipasi kerawanan korupsi (kegiatan pencegahan) dan potensi masalah penyebab korupsi (dengan menangani hulu permasalahan) di lingkungan masing-masing. ${ }^{14}$

Bidang koordinasi dan supervisi adalah sasaran lain dari KPK dalam hal ini kerjasama yang terutama dilakukan dengan polisi dan kejaksaan karena sama-sama penegak hukum yang melakukan pemberantasan korupsi dengan cara :

a. Menindaklanjuti MoU yang sudah dibuat antara KPK, Kejagung, dan POLRI dengan tindakan nyata di lapangan:

1) Mengadakan pertemuan rutin dengan POLRI dan Kejagung.

2) Mengevaluasi proses penanganan kasus yang ditangani oleh Polri dan Kejagung.

b. Mendorong penanganan kasus-kasus korupsi ke daerah (Polda dan Kejati) dengan alternatif tindakan:

1) Diserahkan sepenuhnya sesuai kewenangan Polri dan Jaksa dalam penanganan perkara.

2) Digunakan kewenangan KPK namun dilaksanakan oleh instansi penegak hukum di daerah. 
c. Memantau penanganan kasus-kasus korupsi yang ditangani oleh Polri dan Kejagung:

1) Secara administratif.

2) Check on the spot.

d. Mengambil alih penanganan kasus yang krusial atau yang tidak dapat ditangani oleh Polri dan Kejagung.penegak hukum di daerah. ${ }^{15}$

Bidang sasaran KPK yang terakhir adalah bidang monitoring, disini KPK bertugas menjalankan proses pengawasan terhadap instansi pemerintah, terutama yang bisa mempengaruhi pertumbuhan atau penciutan indeks persepsi korupsi yang dilakukan dengan cara :

a. Melakukan kajian sistem administrasi negara dan sistem pengawasan terhadap lembaga negara/pemerintah secara selektif untuk mendorong dilaksanakannya perubahan sistem dan reformasi birokrasi pada tingkat nasional.

b. Meningkatkan integritas dan efektifitas fungsi pengawasan pada masing-masing instansi melalui restrukturisasi kedudukan, tugas dan fungsi unit/lembaga pengawasan, agar pelaksanaan tugas dan fungsinya dapat dilaksanakan secara independen dan bertanggung jawab. ${ }^{16}$

Pemberian kewenangan sebesar itu tidak sia-sia.Meski belum optimal, pemberantasan korupsi sudah berjalan dan memberikan harapan pada masyarakat.Hal ini tidak lepas dari kesederhananaan birokrasi di KPK. Para penyidik dari KPK bisa langsung berkoordinasi dengan tim penuntut yang juga berada di KPK. Tidak ada hambatan birokrasi institusi atau ego sektoral seperti sering terjadi dalam penanganan kasus yang penanganannya melibatkan banyak lembaga.Salah satu penyebab sering terhambatnya pengusutan kasus korupsi adalah masalah birokrasi yang terlalu rumit. Sebuah surat bisa jadi harus melalui berbagai pintu sebelum sampai ke tangan penerima. Oleh karenanya, tidak heran tersangka korupsi sering melenggang bebas bersembunyi di luar negeri. Penyebabnya bisa jadi karena surat pencekalan yang terlalu lama diproses. 
Profesor Hikmawanto Juwana, guru besar Fakultas Hukum UI, mengatakan bahwa ada tiga factor yang membuat KPK disebut sebagaisuper body.

a. Pertama adalah kewenangan yang terkait dengan proses hukum. Mulai dari penjebakan hingga penuntutan semua dilakukan KPK, bahkan KPK tidak dapat mengeluarkan Surat Perintah Penghentian Penyelidikan (SP3). Berbeda dengan kepolisian dan kejaksaan yang dapat mengeluarkan SP3 sehingga mampu menghentikan pengusutan kasus di tengah jalan. Tanpa adanya SP3 berarti semua kasus yang sudah di usut harus berujung ke pengadilan tindak pidana korupsi yang memang di bentuk khusus. Ketiadaan SP3 membuat KPK harus berhati-hati dalam melakukan pengusutan. Mereka tidak bisa sembarangan menetukan status seseorang sebagai tersangka karena apabila tidak terbukti bisa mengurangi kewibawaan KPK.

b. Faktor kedua adalah personel kepolisian dan sumber daya manusia di KPK. Personel kepolisian dan tenaga dari kejaksaan merupakan orang-orang pilihan dan disaring secara ketat melalui proses yang cukup panjang dan memilih yang terbaik (best of the best). Para pimpinan KPK dipilih dari seleksi yang ketat. Di mulai dari pemberitahuan di media massa dan beragam tes, seperti tes psikologi, hingga fit and proper test dihadapan para anggota DPR. Semua itu dilakukan demi mendapatkan pimpinan KPK yang kompeten, berani, memiliki integritas yang baik, cerdas, dan tidak mudah goyah dalam penegakkan hukum.

c. Factor terakhir adalah masalah kesejahteraan, bukan masalah lagi bahwa tingkat kesejahteraan personel KPK melebihi kesejahteraan aparat penegak hukum lainnya. Dan juga KPK di bekali oleh peralatan canggih. Alat sadap yang dimiliki KPK merupakan yang tercanggih dan sesuai dengan standar internasional. Alat sadap tersebut memang tidak dijabarkan spesifikasinya kepada publik, tapi selalu diaudit secara independent oleh auditor independent. Pengauditan ini dilakukan sebagai bentuk pengawasan terhadap penggunaan alat sadap. Personel kpk juga mendapat pelatihan dari badan penyelidik luar negeri, seperti FBI untuk meningkatkan kemampuannya. ${ }^{17}$ 
Dalam menjalankan tugas koordinasi, komisi pemberantasan korupsi berwenang:

a. Mengkordinasikan penyelidikan, penyidikan, dan penuntutan tindak pidana korupsi, menetapkan sistem pelaporan dalam kegiatan pemberantasan tindak pidana korupsi.

b. Meminta informasi tentang kegiatan pemberantasan tindak pidana korupsi kepada instansi yang terkait.

c. Melaksanakan dengar pendapat atau pertemuan dengan instansi yang berwenang melakukan pemberantasan tindak pidana korupsi.

d. Meminta laporan instansi terkait mengenai pencegahan tindak pidana korupsi. ${ }^{18}$

\section{A. Penegakan hukum oleh KPK terhadap penyelesaian tindak pidana korupsi di Indonesia}

Aspirasi masyarakat untuk memberantas korupsi semakin meningkat, karena korupsi telah menimbulkan kerugian yang sangat besar.Untuk itu upaya pencegahan dan pemberantasan korupsi perlu semakin ditingkatkan dan diintensifkan dengan tetap menjunjung tinggi hak asasi manusia dan kepentingan masyarakat.Untuk dapat memberantas korupsi diperlukan lembaga independen yang bebas dari pengaruh kekuasaan negara.Sehingga dibentuklah KPK sebagai lembaga khusus pemberantasan korupsi di Indonesia.

Kasus Sport Center Hambalang: Kasus korupsi proyek Sport Center Hambalang oleh Komisi Pemberantasan Korupsi (KPK) yang menyebabkan negara dirugikan sebesar Rp. 463,66 miliar. Menurut temuan BPK, uang yang dikeluarkan pemerintah untuk Hambalang dari kontrak Rp 1,2 triliun baru Rp 471 miliar, tapi karena masih ada sisa Rp 8 miliar maka jadi Rp 463 miliar, termasuk untuk pengadaan barang jasa. Dalam kasus ini telah menyeret mantan Menpora Andi Malarangeng, Sekjen Kemenpora Wafid Muharram, dan mantan Ketua Umum Partai Demokrat Anas Urbaningrum. ${ }^{19}$.

\footnotetext{
${ }^{18}$ Titik Triwulan Tutik, Op.Cit, Hal 238

${ }^{19}$ Zaenal Arifin, Tindak Pidana Korupsi Dalam Pengadaan Barang Dan Jasa Pemerinta $h$, Jurnal Hukum Responsif Vol. 5 No. 5, Oktober 2017, Fakultas Hukum Universitas Panca Budi, Medan, 2017 hal 59.
} 
Salah satu implikasi dari penerapan ajaran sifat melawan hukum materil dalam penanganan perkara tindakpidana korupsi adalah lebih terbukanya peluang terjadinya penyalahgunaankekuasaan (abuse of power) yang dilakukan aparat penegak hukum.Yang dimaksud penyalahgunaan kekuasaan disini adalah penyalahgunaan kekuasaan yang dilakukan oleh aparat penegak hukum ketika menangani perkara tindak pidana korupsi, baik itu ditahap penyidikan, penyelidikan, maupun dipengadilan.

Kesalahan jabatan yang oleh pembentuk Undang-Undang kita telah dinyatakan sebagai tindak pidana korupsi di dalam pasal 5 sampai dengan Pasal 12 UndangUndang No. 31 Tahun 1999 itu ialah kejahatan-kejahatan yang diatur dalam Pasal 209, 210, 387, 388, 415, 416, 417, 418, 419, 420, 423, 425, dan Pasal 436 KUHP, yakni yang sesuai dengan ketentuan-ketentuan pidana yang diatur dalam Pasal 3 dari Undang-Undang yang sama telah diancam dengan pidana penjara seumur hidup atau pidana penjara paling singkat satu tahun dan paling lama dua puluh tahun. ${ }^{20}$

Penyalahgunaan kekuasaan (abuse of power) semacam ini sesungguhnya tergolong pula jenis korupsi, yaitu korupsi transaktif dan korupsi defentif (pemerasan).Korupsi transaktif adalah adanya kesepakatan timbal balik antara pemberi dan pihak penerima demi keuntungan kedua belah pihak dan dengan aktif diusahakan tercapainya keuntungan ini oleh keduannya.Contohnya, penyuapan terhadap seorang hakim agar mendapat vonis yang menguntungkan. Sedangkan korupsi defensive diartikan pelaku merupakan korban dilakukannya pemerasan, dalam arti tersangka korupsi (sesungguhnya) bukanlah pelaku korupsi, atau tersangka penipuan bukanlahpelaku penipuan, akan tetapi dijadikan korban untuk diperas. Contoh konkritkoropsi defensive adalah seorang ditahan karena tuduhan yang dibuatbuat, sekedar untuk memerasnya.Ia membayar uang suap untuk pembebasannya dan agar tuduhan atas dirinya dicabut. ${ }^{21}$ Padahal, aparat penegakan hukum telah diberi kepercayaan oleh Undang-Undang untuk memberantas kejahatan korupsi.

${ }^{20}$ P.A.F Lamintang, dan Theo Lamintang, Kejahatan jabatan tertentu sebagai tindak pidana korupsi, Sinar Grafika, Jakarta 2011, hal 28

${ }^{21}$ JuniverGirsang, Abuse Of Power, JG Publising, Jakarta 2012, hal 187 
Dalam pemahaman umum, salah satu bentuk kejahatan korupsi adalah tindakan abuse of power oleh para pejabat Negara untuk meemberikan keuntungan bagi dirinya sendiri atau orang lain. Namun, pengertiannya menjadi berbeda, ketika orang yang diberikan kepercayaan oleh masyarakat untuk menangani perkara korupsi, yaitu aparat penegak hukum, justru melakukan penyalahgunaan kekuasaan, misalnya memeras tersangka atau membelokan hukum melalui Putusannya hanya karena adanya imbalan atau kepentingan tertentu. Oleh sebab itu, sudah sepatutnya lembaga-lembaga penegak hukum yang menjalankan kepercayaan public ini terbebas dari praktik-praktik abuse of power. ${ }^{22}$

Persoalannya sekarang adalah perbuatan melawan hukum materil maupun penyalahgunaan kekuasaan harus ada parameternya yang jelas, sehingga tidak terjadi pencampuradukan antara ruang lingkup hukum pidana dan administrative. Dalam konteks ini, muladi memberikan parameter yang seharusnya digunakan ialah asas-asas umum pemerintahan yang baik, yang mengandung prinsip-prinsip : ${ }^{23}$

1. Kepastian hukum (legal certainty)

2. Kesamaan (equality)

3. Keseimbangan (proportionality)

4. Kecermatan (carefulness)

5. Motivasi (motivation)

6. Tidak menyalagunakan kewenangan (non misuse of competence)

7. Permainan yang wajar (fairplay)

8. Keadilan dan kewajaran (reasonableness and prohibition of arbitraireness)

9. Menanggapi harapan yang wajar (meeting raised expectation)

10. Peniadaan akibat putusan yang batal (undoing the consequences of an annulled decision),

11. Perlindungan dan pandangan hidup atau cara hidup pribadi (protecting the personal way of life).

Namun demikian, menurut Muladi, agar tidak terjebak pada parameter yang masuk jurisdiksi hukum administrasi (maladministraction), atau hukum perdata, maka 
perbuatan-perbuatan diskresioner tersebut harus pula mengandung elemen-elemen yang bernuansa:

1. Kecurangan (deceit)

2. Manipulasi

3. Penyesatan (misrepresentation),

4. Penyembunyian kenyataan (concealment of facts),

5. Pelanggaran kepercayaan (breach of trust),

6. Akal-akalan (subterfuge)atau pengelakan peraturan (illegal circumvention)

Suatu hal yang membedakan KPK dengan institusi penegak hukum lainnya adalah kewenangan yang dimiliki oleh KPK. Lembaga pemberantasan korupsi ini memiliki kewenangan yang sangat luas.KPK bisa melakukan penyelidikan, penyidikan, hingga penuntutan di pengadilan tindak pidana korupsi.Belum lagi kewenangan KPK untuk melakukan penyadapan, pencekalan, meminta laporan kekayaan, hingga membatalkansebuah transaksi keuangan dan memblokir rekening atau kekayaan seseorang yang menjadi tersangka kasus korupsi. ${ }^{24}$ Orang bijak mengatakan, Power tends to corrupt, demikian pula halnya dengan KPK. Kewenangan seluas itu jika tidak disertai dengan pengawasan yang lebih baik bisa disalahgunakan untuk merugikan orang lain. Hal ini sudah terbukti dengan kasus AKP Suparman, kasus ini mencuat pada tahun 2006, yaitu ketika suparman yang menjadi penyidik di KPK ketahuan memeras saksi dalam pemeriksaan kasus korupsi PT. Industri Sandang Nusantara.Suparman waktu itu mengancam saksi Tintin Surtini untuk memberikan sejumlah uang agar tidak dijadikan sebagai tersangka. Pada akhirnya Tintin memberikan uang sebesar Rp. 439.000.000 secara bertahap kepada Suparman. Di persidangan khusus tindak pidana korupsi, suparman terbukti melakukan pemerasan dan dihukum delapan tahun penjara. ${ }^{25}$ Kasus suparman ini menunjukan bahwa tidak semua anggota KPK adalah malaikat yang tidak punya dosa.Mereka hanyalah manusia biasa, bisa saja menyalahgunakan wewenang yang dimilikinya.Tidak ada badan khusus yang mengawasi sepak terjang KPK, layaknya Polisi diawasi oleh Komisi Kepolisian Nasional.Pengawasan KPK langsung dilakukan

${ }^{24}$ Diana Napitupulu, KPK in Action, Raih Asa Sukses, Jakarta 2010, Hal 83

${ }^{25}$ Ibid, hal 83 
oleh rakyat melalui DPR dan Lembaga Swadaya Masyarakat anti korupsi.Pengawasan oleh DPR dilakukan lewat mekanisme rapat dengan pendapat yang dilakukan secara berkala atau setelah merespon isu yang berkembang dimasyarakat.Pada rapat dengan pendapat tersebut, KPK diwakili oleh unsur-unsur pimpinan. ${ }^{26}$

Selain pengawasan secara eksternal melalui peran anggota dewan dan masyarakat lewat LSM, secara internal KPK juga memiliki sistem pengawasan sendiri.Belajar dari kasus AKP Suparman, KPK membentuk Tim Intelejen Internal. Namanya saja intel, sudah pasti mereka melakukan pengawasan secara terselubung. Mereka berasal dari anggota KPK sendiri yang dipilih dan dilatih secara khusus di tempat yang khusus pula. Hanya pimpinan KPK yang mengetahui timintelejen ini, anggota yang lain tidak. Tim ini tetap menjalankan tugas sebagai anggota KPK seperti biasa, hanya mereka mendapat tugas tambahan untuk mencermati tindak tanduk rekan mereka.Tindakan intelejen ini diharapkan bisa dengan mudah menangkap basah anggota KPK yang melakukan pelaggaran.KPK juga menciptakan sistem dan mendorong para anggotanya untuk melakukan pelaporan atas pelanggaran yang terjadi didalam tubuh KPK. Keberadaan tim ini dan dorongan menjadi pelapor terungkap dalam rapat dengar pendapat antara KPK dan Komisi III DPR pada tanggal 9 Juni 2008. ${ }^{27}$ Meskipun demikian, ternyata saat ini pimpinan KPK sendiri yang terjerat dengan dugaan pelanggaran aturan hukum.Ketua KPK non aktif, Antasari Azhar, ternyata kedapatan menemui Anggoro Widjojo di Singapura.Padahal saat itu Anggoroditenggarai tengah memiliki masalah hukum.

Undang-Undang tentang KPK dengan tegas melarang pimpinan KPK untuk menemui seseorang yang sedang terlibat perkara. Pasal 36 ayat 1 menyebutkan bahwa pimpinan KPK dilarang mengadakan hubungan langsung atau tidak langsung dengan tersangka atau pihak lain yang ada hubungan dengan perkara tindak pidana korupsi yang ditangani KPK dengan alasan apapun.

\footnotetext{
${ }^{26}$ Ibid

${ }^{27}$ Ibid, hal 84
} 


\section{E. PENUTUP}

KPK sebagai lembaga anti rasuah dalam memerangi korupsi memerlukan komitmen kuat dan kerja sama serta koordinasi yang baik antar instansi pemerintah dan aparat penegak hukum. Tugas memberantas korupsi hanya dapat dilakukan apabila semua komponen bangsa bersatu dan saling mendukung dalam segala upaya pemberantasan korupsi.Undang-Undang Nomor 30 Tahun 2002 secara jelas sudah memberikan kewenangan kepada KPK yang sangat kuat dan besar untuk melakukan pemberantasan korupsi secara sistemik dan tidak pandang bulu dalam menyeret para koruptor menjadikan KPK sebagai tongggak utama dalam pemberantasan korupsi. Dengan adanya KPK satu demi satu pejabat pemerintah mulai masuk dalam perangkap KPK dan triliunan uang negara pun terselamatkan.

Upaya penegakan hukum yang dilakukan oleh KPK terhadap penyalahgunaan kewenangan yang dilakukan penegak hukum dalam menyelesaikan tindak pidana korupsi yaitu dengan mengoptimalkankewenangan dan Independensi serta integritas Komisi Pemberantasan Korupsi Republik Indonesia sebagai lembaga negara yang melaksanakan koordinasi, supervisi, penyelidikan dan penyidikanbahkan sampai penuntutan terhadap penyelenggaraan pemerintahan yang dilaksanakan oleh aparatur pejabat negara sebagai bagian dari penyelenggaraan negara. Secara garis besar sasaran KPK dalam penegakan hukum dibagi menjadi 4 (empat) bidang, yakni penindakan, pencegahan, koordinasi dan supervisi, serta monitoring. Ini dilakukan untuk melaksanakan tupoksinya dengan baik untuk menindak dengan tegas sesuai aturan hukum yang berlaku maupun mencegah Tindak Pidana Korupsi agar tidak terulang lagi dimasa depan. 


\section{DAFTAR PUSTAKA}

Abidin, Zaenal bin Syamsuddin. "Jihad Melawan Korupsi", Pustaka Imam Abu Hanifah, Jakarta, 2008.

Abidin, Zaenal dan Endri. "Kinerja Efisiensi Teknis Bank Pembangunan Daerah: Pendekatan Data Envelopment Analysis (DEA)".Jurnal Akuntansi dan Keuangan.Vol. 11 No. 1 Hal 21-29.2009.

AdamiChazawi, 2005. Kejahatan Mengenai Pemalsuan. Rajawali Pers. Bandung.

Ahmad Ali, Menguak Teori Hukum (Legal Teory) dan Teori Peradilan termasuk Interprestasi Undang - Undang (Legisprudence), Jakarta Kencana Pranada Media Group 2010

Ahmad-Dzakirin,http://ahmeddzakirin.blogspot.com/2010/09/bab-ii-konsep-negaradalam-islam-html

Akbar, Nasher. "Analisis Efisiensi Organisasi Pengelola Zakat Nasional Dengan Pendekatan Data Envelopment Analysis”, Jurnal TAZKIA, Vol.4 No.2, Agustus-Desember 2009.

Al-Quran dan Terjemahannya. Departemen Agama, Jakarta, 2004.

Amirudin, Korupsi dalam pengadaan barang dan jasa, Genta Publishing, Yogyakarta 2010

Andi Hamzah, Perbandingan Pemberantasan Korupsi di Berbagai Negara,Jakarta : Sinar Grafika, 2005.

Arief, Barda Nawawi. 1996. Masalah Penegakan Hukum dan Kebijakan Penanggulangan Kejahatan.PT. Citra Aditya Bakti. Bandung

Boediono. 1990. Ekonomi Moneter. BPFE.Yogyakarta.

Diana napitupulu, kpk in action, raih asa sukses, Jakarta 2010

Dina Pertiwi Lela. "Efisiesi Pengeluaran Pemerintah Daerah di Provinsi Jawa Tengah", Jurnal Ekonomi Pembangunan Vol.12 No.2 Hal: 123 - 139, Yogyakarta, 2007.

Ermansjah Djaja, Memberantas Korupsi Bersama KPK, Cet. II, Sinar Grafika, Jakarta, 2009

F.Agyya..2010. Kitab Undang-Undang Hukum Pidana.AsaMandiri.JakartaH.A.R. Gibb, The Nodern Trends in Islam, (Chichago: The Univesity Of Chichago Press, 1950

Hadad, Muliaman D., dkk.2003.Pendekatan Parametrik Efisiensi Perbankan Indonesia.www.bi.go.id.Diakses pada tanggal 16 Maret 2015.

Hans Kelsen, General Theory of law and state, diterjemahkan oleh Rasisul

Harie Tuesang, Seminar pencegahan dan pemberantasan korupsi Topik II

HB. Sutopo, Penelitian Kualitatif Baagian II, (Surakarta:UNS Press, 1988)

Ivan Yustiavandana-Arman Nevi-Adiwarman, Tindak Pidana pencucian Uang di Pasar Modal, Bogor :Ghalia Indonesia, 2010. 
Jimly Asshiddiqie, Pengantar Ilmu Hukum Tata Negara Jilid II, Sekertariat Jenderal dan Kepaniteraan Mahkamah Konstitusi RI Jakarta, 2006

Jimly Assiddiqie, Pengantar Ilmu Hukum Tata Negara, Rajawali Pers, Jakarta, 2009 Juniver Girsang, Abuse Of Power, JG Publising, Jakarta 2012

Kamus Dewan Edisi keempat Malaysia, dewan bahasa dan pustaka, Malaysia, 2010.

Lilik Mulyadi, Tindak Pidana Korupsi di Indonesia, Normatif, Teoritis, Praktik dan Masalahnya, P.T. Alumni, Bandung, 2007

Martiman Prodjohamidjojo,Tinjauan Yuridis Terhadap Hak Tersangka Untuk Memperoleh Informasi Dalam Perkara Korupsi Oleh Kejaksaan, Bandung: Mandar Maju, 2001.

Muhammad Ali, Kamus Lengkap bahasa Indonesia, Jakarta : Penerbit: Amoni, 1999. Noeng Muhadjir, Metologi Penelitian Kualitatif, Yogyakarta Cet ke 7.1996

P.A.F Lamintang, dan Theo Lamintang, Kejahatan jabatan tertentu sebagai tindak pidana korupsi, Sinar Grafika, Jakarta 2011, hal 28

Philipus M. Hadjon, Perlindungan Hukum bagi Rakyat Indonesia, Surabaya: PT Bina Ilmu, 1987

R. Soesilo, Taktik dan Teknik Penyidikan Perkara Kriminil. Bogor : Politea, 1980.

S. Wojowasito, W.J.S. Poerwadarminta, Kamus Lengkap Inggris-Indonesia, Indonesia-Inggris, Bandung : Hasta, 2006.

Satijipto Raharjo, Ilmu Hukum, Bandung: PT Citra Aditya Bakti, 2000

Soerjono Soekanto. Pengantar Penelitian Hukum. Jakarta: UI Press, 2001.

udarman Danim, Menjadi Peneliti Kualitatif, Bandung. CV. Pustaka Setia 2002

Sudarto.1983. Hukum Pidana dan Perkembangan Masyarakat Kajian terhadap Pembaharuan Hukum Pidana. Sinar Baru. Bandung.

Sudikno Mertokusumo dalam H. Salim HS. Perkembangan Teori Dalam Ilmu Hukum, Jakarta: PT Rajagrafindo Persada, 2010

Sudikno Mertokusumo, Penemuan Hukum Sebuah Penganntar, Yogyakarta Penerbit Liberty, 2009

Sulistyowati Irianto Sinadarta, Metode Penelitian Hukum Konstelasid dan Refleksi Jakarta Yayasan Pustaka Obor Indonesia, 2013

Suteki, Desain Hukum di Ruang Sosial, Thafa Media, Yogyakarta, 2013

Utrecht, E. dan M. Saleh Djinjang.1982. Pengantar Dalam Hukum Indonesia Pradya Paramitha. Jakarta.

Zaenal Arifin, Tindak Pidana Korupsi Dalam Pengadaan Barang Dan Jasa Pemerintah, Jurnal Hukum Responsif Vol. 5 No. 5, Oktober 2017, Fakultas Hukum Universitas Panca Budi, Medan, 2017.

Komisi pemberantasan Korupsi. 2010. Laporan Tahunan 2010. Diakses pada 20 Januari 2015.Dari :www.kpk.go.id/id/publikasi/laporan-tahunan/581-laporantahunankpk-2010 
Komisi pemberantasan Korupsi. 2011. Laporan Tahunan 2011. Diakses pada 20 Januari 2015.Dari :www.kpk.go.id/id/publikasi/laporan-tahunan/580-laporantahunankpk-2011

Komisi pemberantasan Korupsi. 2012. Laporan Tahunan 2012. Diakses pada 20 Januari 2015.Dari :www.kpk.go.id/id/publikasi/laporan-tahunan/955-laporantahunankpk-2012

Komisi pemberantasan Korupsi. 2013. Laporan Tahunan 2013. Diakses pada 20 Januari 2015.Dari :www.kpk.go.id/id/publikasi/laporan-tahunan/1755laporan-tahunankpk-2013

Komisi pemberantasan Korupsi. 2014. Laporan Tahunan 2014. Diakses pada 1 Juni 2015.Dari :www.kpk.go.id/id/publikasi/laporan-tahunan/2590-laporantahunan-kpk-2014

Laporan Indeks Persepsi Korupsi Tahun 2014, Transparancy International Indonesia Peraturan Perundang-Undangan

Undang-Undang Dasar Negara Republik Indonesia 1945

Kitab Undang - Undang Hukum Acara Pidana (KUHAP).

Kitab Undang - Undang Hukum Pidana (KUHP).

Undang-udang Nomor 31 Tahun 1999 sebagaimana telah diubah dengan Undangundang Nomor 20 Tahun 2001 tentang Perubahan atas Undang-Undang Nomor 31 Tahun 1999 tentang Pemberantasan Tindak Pidana Korupsi 